\title{
PERAN TOKOH MASYARAKAT DALAM MENINGKATKAN PENDIDIKAN DI PUSAT KEGIATAN MASYARAKAT (PKBM) BINA MANDIRI CIPAGERAN KECAMATAN CIMAHI UTARA
}

\author{
${ }^{1}$ Siti Juariah, ${ }^{2}$ Novi Widiastuti \\ 1,2 IKIP SILIWANGI \\ ${ }^{1}$ sitijuariah14030003@gmail.com,2noviw9@gmail.com
}

\begin{abstract}
ABSTRAK
Bertolak pada permasalahan yang peneliti temui dilapangan yaitu : Terdapat kecenderungan umum bahwa pendidikan non formal dihadapkan dengan beragai permasalahan, maka tujuan dari penelitian ini diantaranya : 1 . Untuk mengetahui perencanaan Peran Tokoh Masyarakat dalam Memajukan Pendidikan di Pusat Kegiatan Belajar Masyarakat (PKBM), 2. Untuk mengetahui pelaksanaan Peran Tokoh Masyarakat dalam Memajukan Pendidikan di Pusat Kegiatan Belajar Masyarakat (PKBM). 3. Untuk mengetahui hasil Peran Tokoh Masyarakat dalam Memajukan Pendidikan di Pusat Kegiatan Belajar Masyarakat (PKBM), 4. Untuk mengetahui fakto-faktor yang mempengaruhi masyarakat dalam memajukan pendidikan non formal di PKBM Bina Bina Mandiri. Metode yang digunakan dalam penelitian ini menggunakan metode deskriptif kualitatif dengan menggunakan pengumpulan data berupa observasi, wawancara, dokumentasi dan studi litaratur. Hasil dari penelitian ini menunjukan bahwa : 1) Peran tokoh masyarakat dalam pelaksanaan memajukan pendidikan di PKBM Bina Mandiri sebagai pemrakarsa, motivator, pengelola dan penyedia sarana dan prasarana, 2) Tokoh masyarakat sebagai pemrakarsa memiliki gagasan dan melakukan rapat bersama pengelola untuk merencanakan program pendidikan non formal, sebagai pengelola ikut serta memantau bahkan membantu tutor dalam pembelajaran, sebagai tutor melaksanakan pembelajaran yang disesuaikan menurut minat dan kebutuhan warga belajar, sebagai motivator memberi pengarahan, informasi dan mengingatkan agar partipasinya meningkat serta memfasilitasi tempat pembelajaran,
\end{abstract}

\section{Kata Kunci : Partisifasi, Pendidikan, Tokoh Masyarakat}

\section{PENDAHULUAN}

Perkembangan ilmu pengetahuan dan teknologi membawa pengaruh besar terhadap kehidupan manusia, yang menimbulkan berbagai macam permasalahan dari berbagai aspek terutama dalam hal menghadapi masuknya budaya barat ke dalam negeri. Dengan adanya peristiwa ini warga negara yang mempunyai kekurangan dalam pendidikan mengalami kesulitan untuk beradaptasi dalam menghadapi era globalisasi tersebut tanpa bisa memilah mana yang baik untuk diikuti dan mana yang justru dapat merugikan bangsa. Oleh karena itu dibutuhkan masyarakat yang mempunyai tingkat sumber daya manusia yang baik agar dapat bersaing dimasa yang akan datang. Dalam upaya pemberdayaan manusia maka pendidikan menjadi hal yang sangat penting melihat peran pendidikan yang dapat menentukan kesuksesan seseorang dimasa yang akan datang khususnya dalam mengahadapi era globalisasi. 
Pendidikan merupakan suatu usaha sadar dan sistematis yang dilakukan oleh orangorang yang bertanggung jawab untuk mempengaruhi peserta didik atas pertumbuhan jasmani dan perkembangan rohaninya secara optimal agar mempunyai sifat dan tabiat sesuai cita-cita pendidikan (Munib, 2009 : 34).

Dari pengertian diatas jelas bahwa pendidikan merupakan tempat yang sesuai sebagai sarana dalam memperbaiki sumber daya manusia, pendidikan yang diberikan oleh guru kepada peserta didik telah disusun secara sistematis oleh pemerintah mulai dari tingkat SD, SMP, SMA sampai tingkat perguruan tinggi. Dari segi pelaksanaannya pemerintah juga mempesiapkan pendidikan dari mulai pembuatan kurikulum, pengadaan materi ajar, sarana sekolah maupun pelatihan guru dan tenaga kependidikan. Hal ini dilakukan sebagai upaya pemerintah dalam mempersiapkan negara dimasa yang akan datang agar mampu mencapai tujuan nasional pendidikan yang tertuang dalam Undang-undang nomer 20 tahun 2003 Bab II Pasal 3 yang menjelaskan bahwa pendidikan bertujuan sebagai tempat untuk mengembangkan kemampuan dan watak peserta didik agar menjadi manusia yang beriman dan bertaqwa kepada tuhan Yang Maha Esa, berakhlak mulia, berilmu, kreatif, mandiri dan menjadi warga negara yang bertanggung jawab.

Pendidikan mempunyai beberapa faktor yang mendukung dalam proses pelaksanaannya yaitu faktor dari dalam (intern) yang meliputi kondisi fisik siswa baik jasmani maupun rokhani dan faktor dari luar (Ekstern) yaitu keadaan lingkungan keluarga, sekolah dan masyrakat. Kedua faktor tersebut harus berjalan secara seimbang karena mempunyai peranan yang sama penting untuk menciptakan pendidikan yang dapat mencapai cita-cita yang dimaksud. Masyarakat merupakan faktor yang berpengaruh cukup besar terhadap belajar siswa karena keberadaan siswa didalam lingkungan kehidupan masyarakat yang hampir setiap hari dapat mereka lihat (Slameto, $2010: 60-72$ ).

Kehidupan masayarakat di lingkungan Pusat Kegiatan Belajar Masyarakat (PKBM) selain dapat digunakan sebagai contoh dalam pembelajaran juga mempunyai peran untuk ikut serta dalam praktik kelancaran penyelenggaran pendidikan. Keberadaan masyarakat dalam pendidikan mengacu pada UU nomor 20 tahun 2003 tentang sistem pendidikan nasional pasal 8 yang berbunyi "Masyarakat berhak berperan serta dalam perencanaan, pelaksanaan, pengawasan, dan evaluasi program pendidikan" dan pasal 9 yang berbunyi sebagai berikut "Masyarakat berkewajiban memberikan dukungan sumber daya dalam penyelenggaraan pendidikan".

Dengan demikian jelas bahwa sekolah membutuhkan dukungan dari berbagai sumber daya baik dari lingkungan keluarga, masyarakat dan pemerintah agar dapat mewujudkan pendidikan yang berkualitas. Dukungan yang dimaksud bukan hanya dari segi materi bisa juga dengan memberikan sumbangan berupa tenaga, keikutsertaan dalam kegiatan sekolah maupun pemikiran yang berkaitan dengan kemajuan sekolah. Selain itu masyarakat juga bisa berperan sebagai teladan bagi siswa melihat masyarakat berada dilingkungan sekolah yang setiap hari dapat dilihat aktifitas kehidupannya. Namun Kehidupan masyarakat disekitar sekolah tentunya mempunyai bermacammacam karakter dan juga profesi hal ini dapat dijelaskan melalui contoh misalnya dilingkungan sekolah terdiri dari orang-orang yang tidak terpelajar, penjudi, suka mencuri dan mempunyai kebiasaan yang baik akan mempunyai pengaruh yang buruk 
terhadap siswa yang berada disitu akibatnya pembelajaran akan terganggu dan bahkan kehilangan semangat belajar karena perhatiannya yang semula terpusat oleh pelajaran berpindah pada kegiatan yang dilakukan pada orang-orang yang berada disekitarnya. Sebaliknya jika masyarakat yang hidup dalam lingkungan sekolah adalah orang-orang terpelajar, yang mendidik anak-anaknya untuk bersekolah, antusias akan cita-cita yang luhur yaitu masa depan anaknya maka mereka juga akan terpengaruh ke dalam hal yang baik sehingga dapat mendorong mereka lebih giat belajar.

Sekolah non formal atau PKBM dibuat atas keinginan masyarakat yang digunakan untuk memenuhi kebutuhan seluruh masyarakat bersangkutan. Oleh karena itu sekolah (PKBM) harus selalu menyesuaikan dengan masyarakat mengikuti kebudayaan masyarakat sekitar baik dari segi kurikulum maupun pengelolaannya. Dalam sejarah perkembangan, sekolah mampu memimpin didepan masyarakat dari berbagai segi sehingga melupakan sejarah awal bahwa sekolah merupakan rintisan yang dibuat oleh masyarakat. Keberadaan sekolah yang memimpin didepan masyarakat memunculkan berbagai masalah antara lain dari sekolah yang cenderung arogan terhadap masyarakat tidak perduli terhadap keberadaan masyarakat (individual), adanya keengganan masyarakat dalam memanfaatkan fasilitas sekolah, kesulitan meminta ijin dalam kegiatan yang akan dilakukan di masyarakat sehingga sekolahpun mengalami kesulitaan dalam mendapatkan dukungan dari masyarakat. Akibatnya kini sekolah tertinggal dari masyarakat karena kemajuan teknologi lebih dulu masuk di dalam lingkungan masyarakat daripada sekolah. Sekarang sekolah lebih banyak belajar dengan masyarakat mengingat masyarakatlah yang memiliki sumber daya yang memungkinkan untuk mengembangkan berbagai inovasi sedangkan sekolah hanya berperan serta untuk mencetak manusia agar menjadi manusia yang berfikir inovatif.

Menjelaskan uraian diatas sekolah memang harus selalu menyalurkan pemikiran ideide masyarakat setempat melalui penyelenggaraan pendidikan non formal, memanfaatkan fasilitas seoptimal mungkin untuk belajar, memperhatikan dan menyesuaikan terhadap kebiasaan masyarakat membaur menjadi satu sehingga masyarakat bisa mempunyai rasa memiliki atas sekolah tersebut secara otomatis sekolah akan mendapat dukungan dari masyarakat setempat. Masyarakat juga dapat memberi keuntungan terhadap perkembangan pribadi siswa melalui keikutsertaannya dalam kegiatan masyarakat. namun hal ini juga dengan syarat memperoleh batasan atau tidak berlebihan, karena kegiatan belajar akan terganggu jika kegiatan yang diikuti oleh siswa dalam masyarakat terlalu banyak terlebih apabila siswa tidak bisa mengatur waktu dengan baik. Perlunya mengusahakan lingkungan sekolah yang baik adalah sangat penting terhadap pendidikan karena dapat membawa pengaruh yang positif terhadap siswa sehingga dapat meningkatkan minat belajar siswa. Antara masyarakat dan sekolah (PKBM) saling membutuhkan. Masyarakat membutuhkan agar siswa dibina secara optimal oleh PKBM, sebaliknya PKBM membutuhkan agar masyarakat membantu kelancaran proses belajar di sekolah dengan memberikan berbagai macam fasilitas.

\section{TINJAUAN TEORITIS}

Peran serta masyarakat (PSM) merupakan keikut sertaan individu,keluarga dan kelompok masyarakat dalam setiap menggerakan upaya kesehatan yang juga merupakan tanggung jawab sendiri,keluarga dan masyarakatnya. Dalam world Healt 
Assembly 1997, peran masyarakat adalah proses untuk mewujudkan kerja sama kemitraan antara pemerintah dan masyarakat setempat dalam merencakan ,melaksanakan dan memanfaatkan kegiatan kesehatan sehingga diperoleh manfaat berupa peningkatan kemampuan swadaya masyarakatmasyarakat berperan dalam menentukan prasarana dan pemeliharaan teknologi tepat guna dalam pelayanan kesehatan.

Menurut Kleis et al. (1986) pendidikan nonformal adalah biasanya berkaitan dengan misi yang mendesak dan praktis, tempat pendidikan biasanya di luar kelas atau di situasi belajar yang sebenarnya, bukti memiliki ilmu pengetahuan dinilai dari keterampilannya (bukan dari sertifikatnya), biasanya tidak terlalu terikat dengan ketentuan yang ketat, isi, staf atau strukturnya tidak terorganisasi, peserta biasanya bersifat sukarela, biasanya merupakan aktivitas sampingan, pelajaran jarang bertingkat dan berurutan, biaya pendidikan biasanya lebih murah dari pendidikan formal, persyaratan penerimaan pesertanya lebih ringan, penilaian keberhasilan peserta berdasarkan kemampuan mendemonstrasikan keterampilan, dan tidak terbatas untuk peserta dan kurikulum tertentu, tetapi dapat diperbarui dan dikembangkan.Membangun Masyarakat Pemberdaya (How To Bulid Empowering Sociey) Dipublikasikan Pada Peran Dan Ekspektasi Pendidikan Nonformal Dalam Menghadapi Masyarakat Ekonomi Asean (Mea) - Fip Universitas Negeri Semarang Vol. 1 No. 1 Tanggal 25 May 2015 ISBN: 978-60214314-8-1

\section{METODOLOGI PENELITIAN}

Metode yang digunakan dalam penelitian ini adalah penelitian kualitatif. Penelitian kualitatif adalah penelitian yang menggunakan format deskriptif berupa kata-kata tertulis atau uraian dari oarang-oarang dan prilaku yang dapat diamati. sedangkan menurut John W.Creswell yang di kutip oleh Hamid Patiliam, penelitian kualitatif adalah: "sebuah proses penyelidikan untuk memahami masalah sosial berdasarkan pada penciptaan gambar holistic yang di bentuk dengan kata-kata, melaporkan pendanagn informan secara terperinci dan di susun dalam sebuah latar ilmiah". selanjutnya Bogdan dan Taylor mendefinisikan penilitian kualitatif adalah prosedur penelitian yang menghasilkan data deskriptif berupa kata-kata tertulis atau lisan dari orang-orang dan pelaku yang di amati. Pada bagian ini dikemukakan bahwa, peneliti menggunakan teknik pengumpulan data yang utama yaitu: Observasi, Wawancara, Dokumentasi. Berikut ini dikemukakan teknik penelitian pengumpulan data yaitu:

\section{a. Observasai (pengamatan)}

Metode observasai adalah suatu pengamatan yang sengaja dan sistematis tentang fenomena-fenomena sosial dengan gejala psikis dengan jalan pengamatan dan pencatatan.Observasi adalah alat pengumpulan data yang dilakukan dengan cara mengamati dan mencatat secara sistematik gejala-gejala yang diselidiki. Adapun bentuk obsevasi yang penulis lakukan adalah observasi non parsipan, yaitu peneliti tidak ikut langsung berpartisipasi terhadap apa yang di observasi

\section{b. Wawancara (Interview)}

Wawancara adalah suatu bentuk komunikasi verbal jadi semacam percakapan yang bertujuan untuk memperoleh informasi. Wawancara adalah teknik pengumpulan data 
dengan mengajukan pertanyaan langsung oleh pewawancara kepada responden, dan wawancara responden dicatat atau direkam. Jadi wawancara adalah komunikasi dua oarang atau lebih secara langsung maupun tidak langsung untuk mendapatkan data atau informasi yang jawaban dari responden dicata atau direkam.

c. Dokumentasi

Menurut Suharsimi Arikunto,"dokumentasi adalah mencari data mengenai hal-hal atau variabel berupa catatan, transkip, buku, surat kabar, majalah, notulen rapat, agenda, dan sebagainya"

\section{d. Studi Kepustakaan}

Studi kepustakaan, digunakan untuk mengumpulkan data yang bersifat teoritis yang berhubungan dengan masalah yang diteliti.

\section{HASIL DAN PEMBAHASAN}

PKBM Bina Mandiri Cipageran Desa merupakan salah satu daerah yang berada di wilayah Kelurahan Cipageran Kecamatan Cimahi Utara Kota Cimahi. Untuk mengetahui hasil penelitian secara keseluruhan maka data yang terkumpul dari alat pengumpul data sebagaimana yang telah dijelaskan pada bagian terdahulu dan untuk mengetahui bagaimana Peran Tokoh Masyarakat Dalam Meningkatkan Pendidikan di Pusat Kegiatan Belajar Masyarakat (PKBM) Bina Mandiri Cipageran Cimahi, dilakukan analisis data yaitu dengan menggunakan teknik penjabaran dengan cara menguraikan berdasarkan persentase.

Pengolahan data dilakukan dengan sederhana karena penelitian ini bersifat deskriptif, jadi pengolahan datanya hanya dianalisis menurut isinya. Maka hasil tabulasi angket adalah sebagaimana terlihat dalan tabel-tabel berikut ini:

\section{Tabel 1 Tingkat Pendidikan Tokoh Masyarakat}

\begin{tabular}{clcc}
\hline No & Jawaban & Frekwensi & \% \\
\hline 1 & SD & 0 & - \\
2 & SLTP & 0 & - \\
3 & SMU/Sederajat & 0 & - \\
4 & Akademi & 1 & 100 \\
\multicolumn{2}{|}{ Jumlah } & $\mathbf{1}$ & $\mathbf{1 0 0}$ \\
\hline
\end{tabular}

Sumber data RW 11 Kel. Cipageran

Tabel diatas menggambarkan tingkat pendidikan yang dimiliki Tokoh masyarakat yaitu 100 \% Akademi dari Pendidikan Luar Sekolah. Dari jawaban responden diatas dapat ditarik kesimpulan bahwa tingkat pendidikan yang dimiliki Tokoh Masyarakat memadai dalam pengelolaan program Pendidikan Non Formal, hal ini sangat mendukung untuk memajukan program yang ada di PKBM tersebut. 
Tabel 4.2

Pendapat Responden Sejauh mana partisipasi tokoh masyarakat dalam pelaksanaan pembelajaran

\begin{tabular}{clcc}
\hline No & Jawaban & Frekwensi & \% \\
\hline 1 & Tidak pernah & 1 & 20 \\
2 & Selalu & 3 & 20 \\
3 & Kadang-kadang & 1 & 60 \\
& Jumlah & 5 & 100 \\
\hline
\end{tabular}

Sumber angket Observasi

Tabel diatas menggambarkan tentang sejauh mana partisipasi tokoh masyarakat dalam pelaksanaan pembelajaran di PKBM, jawaban dari responden yang belajar di PKBM Bina Mandiri Cipageran yang menjawab tidak pernah, sebanyak setengahnya 1 orang (20\%), dan rasponden yang menjawab selalu sebagian besar, sebanyak 3 orang $(60 \%)$ yang menyatakan kadang-kadang, sebagian kecil sebanyak 1 orang (20\%).

Setelah diperoleh jawaban responden melalui tabel frekwensi, selanjutnya dilakukan pembahasan/memberkan tafsiran terhadap hasil penelitian. Dari temuan di lapangan dan bukti-bukti yang mendukung bahwa tokoh masyarakat mempunyai peran dalam melaksanakan kegiatan belajar, hal ini dapat diketahui bahwa semua warga masyarakat yang ikut berperan dalam kegiatan di PKBM, mengetahui secara jelas tujuan daripada kegiatan yang diselenggarakan oleh tokoh masyarakat dan pengelola PKBM Bina Mandiri. Penulis juga melihat bahwa tokoh masyarakat di lingkungan RW 11 Kelurahan Cipageran sudah mempunyai kinerja yang cukup baik, terlihat pada kegiatan-kegiatan yang dibuatnya bersama dengan pengelola PKBM dalam program yang diselenggarakan oleh PKBM. Dengan adanya peran dari berbagai stakeholder yang ada di sekitar lingkungan PKBM, maka diharapkan dapat mendorong kemandirian kehidupan masyarakat dalam mempersiapkan kompetensi dan kapasitas yang lebih baik, hal ini dapat memunculkan dan memperkuat modal sosial (social capital) yang turut pula dalam mendukung kehidupan masyarakat yang lebih baik (Mulyono, 2018).

\section{KESIMPULAN}

Peran Tokoh Masyarakat Dalam Meningkatkan Pendidikan di Pusat Kegiatan Belajar Masyarakat (PKBM) Bina Mandiri Cipageran Cimahi, yang tumbuh atas kesadaran dan rasa tanggung jawab sosial dari oleh dan untuk masyarakat terutama tokoh masyarakat di wilayah RW 11 Kelurahan Cipageran, bergerak terutama dalam bidang pendidikan, yang secara fungsional dibina dan dikembangkan oleh Dinas Pendidikan Kota, yang bertujuan menanggulangi berbagai permasalahan di bidang pendidikan.

Sesuai analisis pungolahan data menunjukkan sudah terdapat peran tokoh masyarakat dalam meningkatkan pendidikan, akan tetapi perannya masih sedang, sehingga masih perlu peningkatan dalam pelaksanaan tugas dan kewajibannya untuk membina masyakarat berpendidikan agar sesuai dengan harapan yang diprogramkan sejak awal, sehingga diperlukan kerjasama yang baik antara pemerintahan dengan pengurus tokoh 
masayarakat agar dapat menciptakan pendidikan bagi masyarakat yang tidak bisa sekolah ke sekolah formal.

\section{DAFTAR PUSTAKA}

Ansori. AL-B. (2015). Membangun Masyarakat Pemberdaya (How To Bulid

Empowering Sociey). Pada Peran Dan Ekspektasi Pendidikan Nonformal Dalam Menghadapi Masyarakat Ekonomi Asean (Mea) - Fip Universitas Negeri Semarang Vol. 1 No. 1 Tanggal 25 May 2015 ISBN: 978-60214314-8-1

Munib. (2009). Tekhnologi dan Pendidikan. Bandung. Tarsito

Mulyono, D. (2018). THE STRATEGY OF MANAGERS IN MOVING BUSINESS LEARNING GROUP PROGRAM IN PKBM SRIKANDI CIMAHI CITY. Journal of Educational Experts (JEE) Vol 1 (1), 41-50.

Sugiono. (2011). Variabel Penelitian, Jakarta. Rineka Cipta

Slameto. (2010). Pendidikan Non Formal. Jakarta. PT Gramedia.

Undang-Undang (2003). Sistem Pendidikan Nasional. Alfabeta. Bandung

World Healt Assembly (1997). Pendidikan Masyarakat. Jakarta. Gramedia 